\title{
Digital modelling of Québec City churches
}

\author{
P. Côté ${ }^{1}$, R. Caron ${ }^{2}$, L. K. Morisset ${ }^{3}$ \& L. Noppen ${ }^{3}$

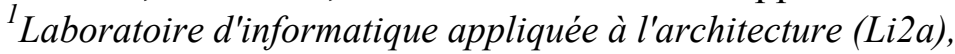 \\ Toulouse, France \\ ${ }^{2}$ Division du design, de l'architecture et du patrimoine, \\ Service de l'aménagement du territoire, Ville de Québec, Canada \\ ${ }^{3}$ Canada Research Chair on Urban Heritage, \\ Université du Québec à Montréal (UQAM), Canada
}

\begin{abstract}
Works on digital modelling of Québec City churches started in 1997, based on the assessment of three objectives laid down at the beginning of the project. Those objectives were: first, to bring to people an overall panorama of the churches of Québec based on synthesized images of church digital models, and to promote churches' architectural heritage values; second, to offer to professionals, high quality 3D digital models, which can be used for visualization and simulation purposes for their own proposed churches' new occupations and functions; and third, to allow students to develop their 3D computer skills and expertise while being introduced to the architectural heritage of Québec churches. The diffusion of modelling results in the form of virtual objects, synthesized images and panorama was at the beginning of the project a major objective. The second objective, to make available $3 \mathrm{D}$ digital models to the current church owner and to professionals, aimed at facilitating the use of information technologies (IT) during the design process, developing their architectural proposals using visualizations and simulations and to communicate and diffuse their own proposals. Finally, regarded as a complex process, digital modelling occupies a privileged place for training students at the School of Architecture of Laval University and, as such, this project has been a privileged opportunity. In this paper, the relevance of this work and its impact are discussed with regard to those objectives and the huge digital archives thus created as a contribution to the architectural heritage of Québec City.
\end{abstract}

Keywords: digital 3D models, digital modelling, process of modelling, modelling by interpretation, churches heritage documentation. 


\section{Introduction}

During the summer of June 1997, the 3D modelling of churches of the Québec City has started, following the contest of Notre-Dame-de-Grâce Church 3D Modelling [1] organized within the framework of the First International Conference on the Future of Church Estate [2]. During this first summer, five students from the School of Architecture of Laval University formed the two teams, which took part in the modelling contest. Those five students were awarded based on the quality of their production, a summer job in 3D modelling. Since then, this work of modelling is the fruit of a continuous collaboration between the School of architecture, the Direction de la Capitale-Nationale of the Ministère de la Culture et des Communications du Québec and the Division du design, de l'architecture et du patrimoine of Service de l'aménagement du territoire, City of Québec. This work is being continued at the present time, in the context of the new territory of the City of Québec, pursuing three original objectives:

1. Diffusion: to generate, starting from the digital models, at the same time high quality synthesized images and panoramas, and virtual objects, in order to support the diffusion of this heritage by various means: Web, CD-ROM and publications.

2. Modelling: to create and provide to owners and professionals a basic but useful material (digital models) from which they would work out through modelling, visualization and simulation their own proposals and projects of restoration and space requalification.

3. Formation: to offer to students in architecture the opportunity to acquire an sound expertise in 3D modelling by interpretation, reading drawings (blueprints), photographs and documents, and in addition, to acquire a thorough knowledge of the architectural churches heritage of Québec City, through this modelling process that proves to be a unique and privileged means of knowledge acquisition.

Furthermore, digital models must serve and play its role as representation, archives and memory of this original architecture. Thus, during the first modelling phase relating to the old city limits, 39 public churches as well as one chapel were modelled. This first phase spreads out over five years. At the summer 2002, the reconfiguration of the city marks a stop in the production of modelled churches, while allowing for the completion of unfinished ones and the realisation of the first website dedicated to these modelling works. When the work resumes, at the summer 2003, 17 other churches have been modelled (see the list in Annexe B).

In the following, we describe each of the three objectives in detail, in order to highlight the relevance of that work of modelling in regard to the results obtained. We also refer to the contribution of this work as digital archives of Québec City churches heritage. 


\section{Diffusion}

At the beginning of the project, diffusion of modelling results in the form of synthesized images and panoramas, and virtual objects was a major objective. Indeed, it became an urgent necessity (the church of Notre-Dame-du-Chemin has been demolished in 1999) to make known to the public the large architectural diversity and richness of the churches of Québec City, but also to present the state of this architectural heritage, thus, providing easily accessible and relevant historical information on each one of them. Furthermore, this work has led to a series of several publications dedicated to promote this heritage, making extensible use of the digital results of modelled churches [3-6].

Another important aspect, which deserves to be associated to the diffusion objective, is the possible visual assessment of the architectural potential of the churches. Indeed, the review of the whole modelling reveals us the architectural potential of churches, formal richness, urban silhouette - essential component of our urban landscape - by their bell-tower as identity district landmark, and as a living area and parish history witness. This visual review has been mainly assured by the creation of a website dedicated to the churches of Québec City.

\subsection{The website of the churches of Québec City}

A first website, dedicated mainly to the 3D modelling of churches is launched during the summer 2001, giving place then to an important press coverage [711]. The quality of this first site is even marked by Bell Sympatico awards "Site of the day" title, in September 2001.

In 2003, the municipalities' fusions through all the Province of Québec forced a reconfiguration of the city's administrative entity and urban limits, thus, adding numerous churches to the city territory. As a consequence, this new configuration commanded a major update of the website. This new website has been online since June 2006 [12].

To date, 56 churches out of 84 indexed churches are fully documented with synthesized panoramas and images resulting from the modelling. But, all 84 churches documentation contains photographs and texts commenting their own history and the one of parishes. The website gives access to this original city information base through three indexes: churches, parishes and localisation (map). Furthermore, the new site offers a link to the preceding website, as a memory of the first stage of churches 3D modelling. Indeed, this website gives an account of an important phase and efforts of documentation, and a statement on the modelling of the churches of old City of Québec [13].

\section{Modelling}

The second objective of this work, modelling, to make available a high quality 3D digital model to the current church owner and to professionals, aims to facilitate the use of information technologies (IT) during the design process and development of architectural proposals using modelling, visualization and 
simulation and, in addition, to communicate and diffuse these same proposals. For this purpose, students are mandated to model the current state of the church. By taking account of the whole work of modelling, an average of 210 hours (six weeks) is necessary to model and render a church of average dimension and complexity - the bigger ones taking twice as much time. For each church, the renderings include: four elevations, two interior and exterior perspectives, one interior panorama and one "virtual object", which allows the exterior visualization of the church building interactively.

As base for refitting some churches square, the City used their 3D digital model. That was the case of the churches of Saint-Roch and Saint-Jean-Baptiste. As well, for recycling the church of Saint-Esprit that now houses the School of Circus of Québec. Moreover, those models are regularly used by professors of the School of Architecture in their architectural design studios, as well as, by finishing students for their thesis project.

The use of 3D digital models is subjected to two requirements: one reference to the student who did the model, and to the Research Laboratory on Identity by Architectural Modelling (LIMA, Laboratoire de recherche sur l'Identité par Modélisation Architecturale) where the work was done; and, another, the City of Québec and the Ministère de la Culture et des Communications within the framework of the Entente de développement culturel, which, since 1997, financed the project for approximately $200 \mathrm{~K} \$$ reserved mainly to modelling, but also the architectural surveys and the website. These references apply also to modified or transformed models for a particular use.

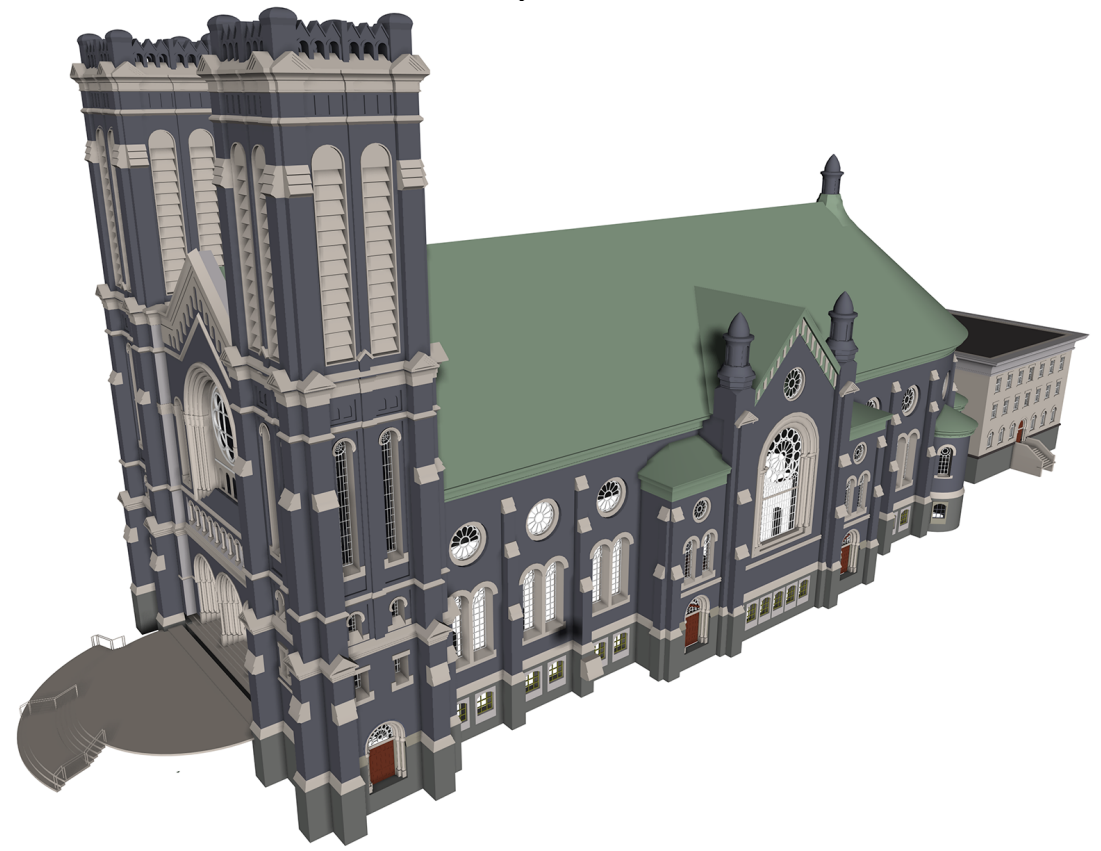

Figure 1: $\quad$ Saint-Roch Church. Mathieu Paradis, 1997. 


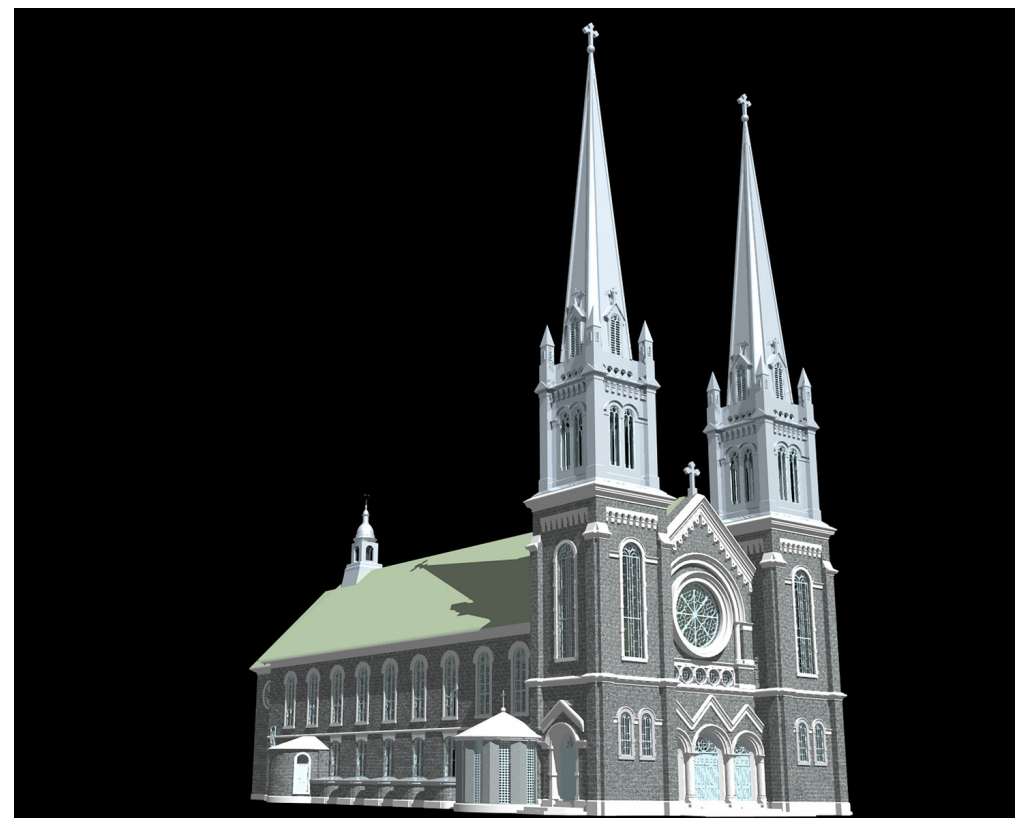

Figure 2: $\quad$ Saint-Charles-de-Limoilou Church. Hugues Poirier, 1999.

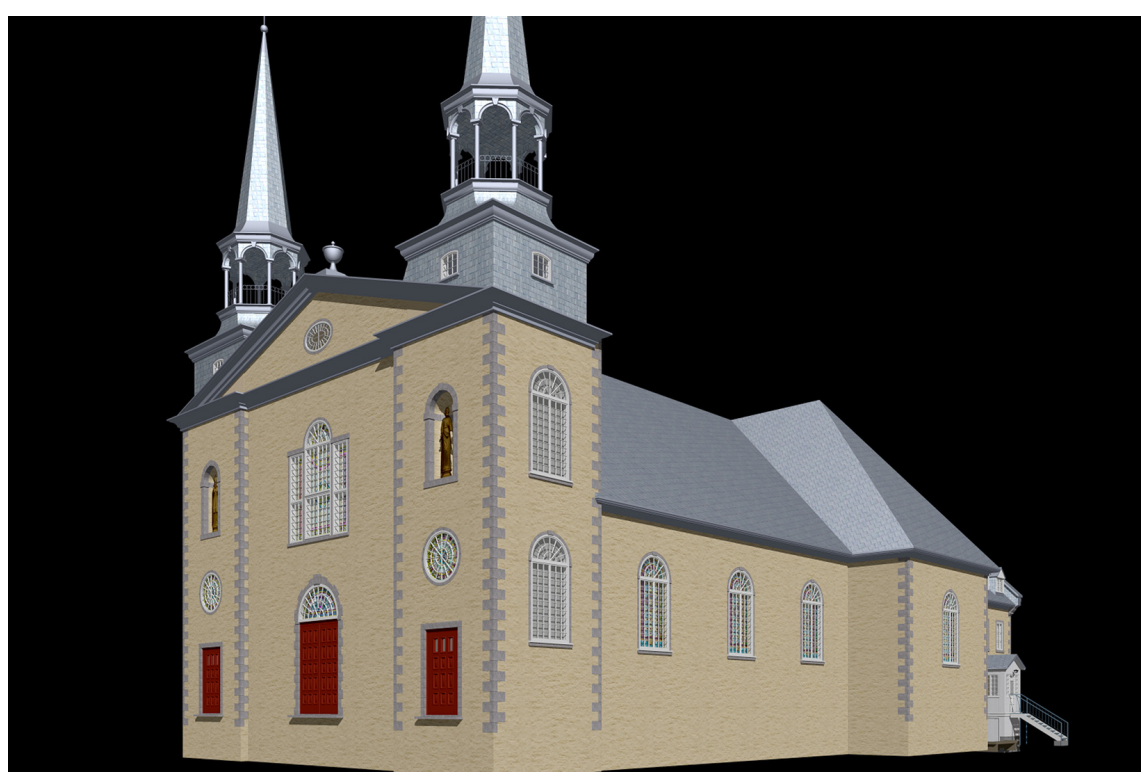

Figure 3: Saint-Charles-Borromée Church. François Cantin, 2003. 
In relation to this second objective is the type of documentation provided for the realization of models. This documentation includes a "protocol of modelling" giving instructions and strategies, specifying the structure of the information within the 3D computer file (nomenclature to be used and provision for 3D data taking into account the parameters of the modelling software used), and finally, describing the type and format of the material to be handed out $(3 \mathrm{D}$ and rendering files format). Benefiting from the experience gained during ten years of continuous work, these documents have evolved and improved to become sound references for 3D modelling by interpretation.

As work examples, the three illustrations in figures 1 to 3 summarize and represent remarkable work of modelling by students, as much as by the quality of the 3D model as for the synthesized material provided. Furthermore, each image corresponds to an identifiable period of the whole production of these 3D digital models and the work progress, that is to say, the church of Saint-Roch, 1997 (fig.1); the church of Saint-Charles-de-Limoilou, 1999 (fig. 2); and the church of Saint-Charles-Borromée, 2003 (fig. 3).

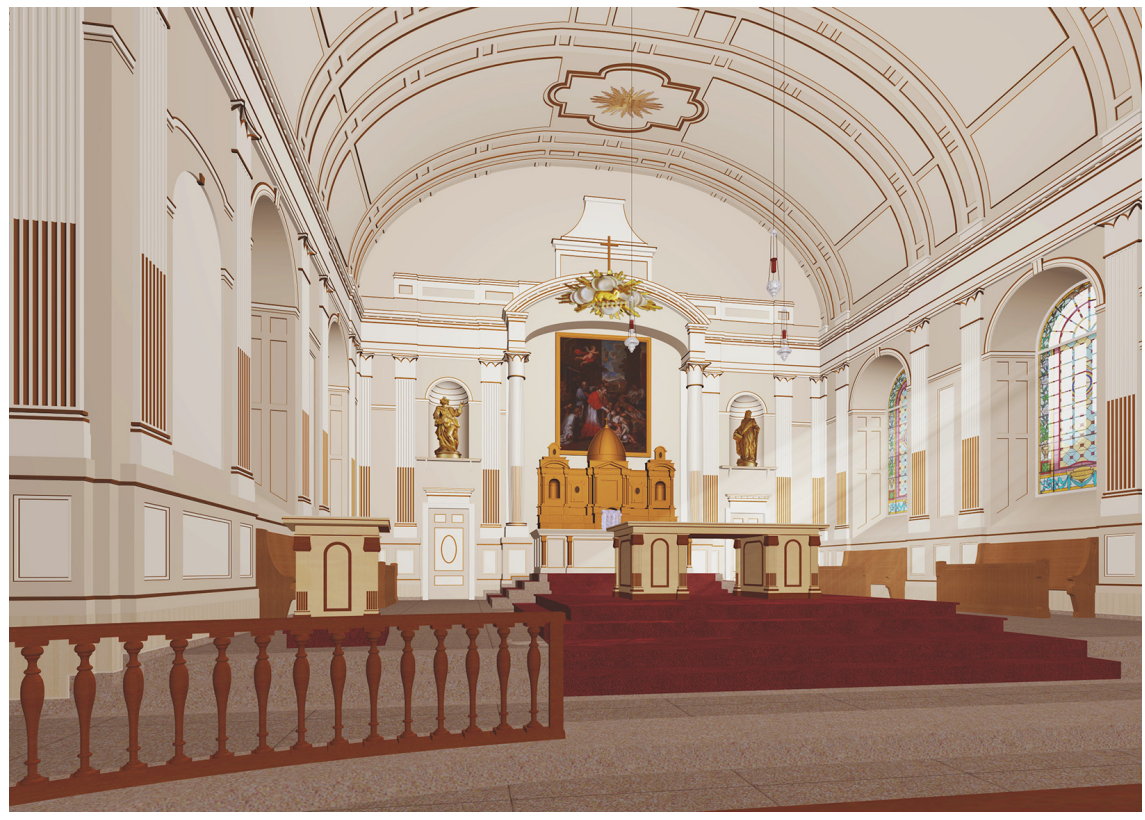

Figure 4: $\quad$ Saint-Charles-Borromée Church. Interior. François Cantin, 2003.

\section{Formation}

Taken as a complex process of making forms that bears many comparisons with the process of design, 3D digital modelling occupies a privileged place in training students at the School of Architecture of Laval University [14]. It is in 
this context that the modelling churches of the City of Québec took place at the LIMA, privileging modelling by interpretation as a process of model realization.

From a teaching point of view, this exercise of passage between $2 \mathrm{D}$ data to $3 \mathrm{D}$ must be examined as propaedeutics to heritage $[15,16]$. It is even more advantageous that each student on average had modelled two churches, which constitutes a remarkable training length of 410 hours in average of learning about church heritage.

During this work, an approach to modelling and know-how are developed, making figure of modelling paradigm as compared to current $3 \mathrm{D}$ digitalization methods, such as laser sweeping beam to building. The approach adopted at the school privileges and this, since the beginning of the project, the use of $2 \mathrm{D}$ documentation (e.g. drawings, blueprints, and photographs) coming from either archives of Province of Québec, Laval University, Diocese, parish or the architect office, in order to learn from the imbed know-how and encoded lessons in that documentation. Indeed, this approach of "modelling by interpretation" refers to the component registered in the documentation which must be decoded, interpreted and restored as a whole at some point during the reading in order to interpret it correctly in 3D. As such, modelling by interpretation becomes a means without equivalent and privileged for the training of the students.

Thus, since the summer 1997, 26 students have contributed to build a unique digital representation of the churches heritage of the City of Québec (see the list of the students, and of the churches modelled in annexes A and B respectively).

\subsection{Documentation and archives}

Another important aspect, which is essential to mention as a direct consequence of all this work, is the regrouping of existing and produced documentation necessary to the churches modelling. At the beginning of each church-modelling project, a self-documentation necessary to model a church is handed-over to the student responsible. As mentioned, this initial documentation often comes from many sources (archives), which thus, are gathered. However, each student is responsible to validate and supplement this documentation by photographs, drawings and if necessary specific surveys from repeated visits to the church site. The documentation validation is a critical step, necessary to ensure the identification differences - in order to correct them - between the current state of the church, which must be modelled, and that represented by the provided documentation. Indeed, without taking into account the church numerous repairs, restorations or additions, the available archives and documentation often represents the project of the church, sometimes in perfect contradiction with the church building on site.

In addition, in certain cases, lack or absence of documentation will require a complete survey of the church. These surveys were also done by students of the School of architecture, under professor supervision, inside ad hoc contract, practical work courses, or rehabilitation design studios. Thus, to date, 16 churches were subjects to a complete survey, all been modelled. 
Lastly, all this additional documentation is gathered and deposited as documentation at the City of Québec's Division du design, de l'architecture et du patrimoine du Service de l'aménagement du territoire.

\section{Conclusion}

In conclusion, the reader is legitimate to question the relevance of this work of churches modelling. However, we believe that it is correct to answer to that question by stressing it in comparison to the objectives stated at the beginning about diffusion, modelling and formation. Thus, this paper hopes to have shown that the answer is more than affirmative for each one of the three objectives.

In addition, what is the impact of this work? To begin with, the results constitute a unique contribution to the knowledge on the heritage of churches of Québec City, thanks to the whole digital documentation thus created, and hence, the archives gathered. Moreover, the lessons learned are many and could be used again, namely on: how to structure and document a church 3D digital model (what is essential); how to learn from the process of modelling by interpretation in the context of heritage development; and, finally, to mention one technical consideration, how to do the work flow to extracting 2D vectors information, for drawing purposes, from a 3D digital model.

This work has benefited from supports from the following organizations: the Social Sciences and Humanities Research Council of Canada (SSHRC), Laval University, the City of Québec and the Ministère de la Culture et des Communications du Québec within the framework of the Entente de développement culturel.

\section{Annexe A}

Table A1: $\quad$ List of 26 participant students.

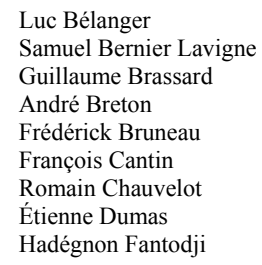

10. Jean-Nicolas Fortin

11. Virginie Gagnon

12. Étienne Germain

13. Geneviève Giguère

14. Le Hoang Khanh

15. David Lavoie

16. Stéphane B. Lessard

17. Nicolas Lévesque Tremblay

18. Éric Longchamp 


\section{Annexe B}

Table B1: $\quad$ List of 56 modelled churches to date (January 2007).

1. Baptist Church (arr. de La Cité)

2. Françiscaines, chapelle des (désaffectée) (arr. de La Cité)

3. Notre-Dame-de-Grâce, église de (recyclée) (arr. de La Cité)

4. Notre-Dame-de-la-Garde, église de (arr. de La Cité)

5. Notre-Dame-de-Québec, cathédrale (arr. de La Cité)

6. Sacré-Coeur-de-Jésus, église du (arr. de La Cité)

7. Saint-Augustin-deDesmaures, église de (Ville de Saint-Augustin-deDesmaures)

8. Saint-Charles-Garnier, église de (arr. de Sainte-FoySillery)

9. Saint-Dominique, église de (arr. de La Cité)

10. Sainte-Maria-Goretti, église de (arr. de Charlesbourg)

11. Saint-Esprit, église du (recyclée) (arr. de Limoilou)

12. Saint-François-d'Assise, église de (arr. de Limoilou)

13. Saint-Ignace-de-Loyola, église de (arr. de Beauport)

14. Saint-Louis-de-Courville, église de (arr. de Beauport)

15. Saint-Michel-de-Sillery, église de (arr. de Sainte-FoySillery)

16. Saint-Paul-Apôtre, église de (arr. de Limoilou)

17. Saint-Sacrement, église du (arr. de La Cité)

18. Saint-Thomas-d'Aquin, église de (arr. de Sainte-Foy-Sillery)
19. St. Andrew's Church (arr. de La Cité)

20. Bon-Pasteur, église du (arr. de Charlesbourg)

21. Holy Trinity, cathédrale (arr. de La Cité)

22. Notre-Dame-de-JacquesCartier, église de (arr. de La Cité)

23. Notre-Dame-de-la-Paix, église de (recyclée) (arr. La Cité)

24. Notre-Dame-des-Victoires, église de (arr. de La Cité)

25. Saint-Albert-le-Grand, église de (arr. de Limoilou)

26. Saint-Charles, église de (arr. de Limoilou)

27. Saint-Coeur-de-Marie, église de (recyclée) (arr. de La Cité)

28. Sainte-Cécile, église de (arr de Charlesbourg)

29. Sainte-Monique, église de (arr. des Rivières)

30. Saint-Félix-de-Cap-Rouge, église de (arr. Laurentien)

31. Saint-François-Xavier, église de (arr. des Rivières)

32. Saint-Jean-Baptiste, église de (arr. de La Cité)

33. Saint-Louis-de-France, église de (arr. de Sainte-Foy-Sillery)

34. Saint-Pascal-Baylon, église de (arr. de Limoilou)

35. Saint-Pie-X, église de (arr. de Limoilou)

36. Saint-Sauveur, église du (arr de La Cité)

37. Saint-Vincent-de-Paul, église de (désaffectée) (arr. de $\mathrm{La}$ Cité)
38. St. Michael's Church (arr. de Sainte-Foy-Sillery)

39. Chalmers-Wesley's Church (arr. de La Cité)

40. La-Nativité-de-Notre-Dame, église de (arr. de Beauport)

41. Notre-Dame-de-

l'Annonciation, église de (arr. Laurentien)

42. Notre-Dame-de-Pitié, église de (arr. de La Cité)

43. Notre-Dame-du-Chemin, église de (démolie) (arr. de La Cité)

44. Saint-André, église de (arr. des Rivières)

45. Saint-Charles-Borromée, église (arr. de Charlesbourg)

46. Saint-Denys-du-Plateau, église de (arr. de Sainte-Foy-Sillery)

47. Sainte-Claire-d'Assise, église de (arr. de Limoilou)

48. Sainte-Odile, église de (arr de Limoilou)

49. Saint-Fidèle, église de (arr. de Limoilou)

50. Saint-Grégoire-deMontmorency, église de (arr. de Beauport)

51. Saint-Joseph, église de (désaffectée) (arr. de La Cité)

52. Saint-Malo, église de (arr. de La Cité)

53. Saint-Patrick, église de (arr. de La Cité)

54. Saint-Roch, église de (arr. de La Cité)

55. Saints-Martyrs-Canadiens, église des (arr. de La Cité)

56. Saint-Zéphirin-de-Stadacona, église de (arr. de Limoilou)

\section{References}

[1] Morisset, L.K., Le concours de modélisation de l'église Notre-Dame-deGrâce, Québec, Revue ARQ, (août), no 98, p. 27, 1997.

[2] Noppen, L., Morisset, L.K., Caron, R., La conservation des églises dans les villes-centres, Actes du premier colloque international sur l'Avenir des biens d'Église, Sillery, Septentrion, 1997.

[3] Ordem International (éd.), Bibli-mots, Présentation en objet virtuel des modèles 3D d'une sélection des églises de Québec, CD-ROM, 2002. 
[4] Morisset, L.K., La mémoire du paysage. Histoire de la forme urbaine d'un centre-ville : Saint-Roch, Québec, Québec, Les Presses de l'Université Laval, p. 45, 147, 158, 159 et page couverture, 2001.

[5] Noppen, L. \& Morisset, L.K., L'architecture de Saint-Roch, Guide de promenade, Québec, Les Publications du Québec, p. 36, 39, 48, 49, 2000.

[6] Noppen, L., Morisset, L.K., Caron, R., La conservation des églises dans les villes-centres, p. 200-202 et page couverture.

[7] Contact, magazine des diplômés et des partenaires de l'Université Laval, (hiver), p. 5, 2002.

[8] Leclerc, D., Une visite virtuelle des églises d'ici, Le Carrefour de Québec, édition centre-ville, (21 octobre), vol. 8, no 4, 2001.

[9] Larose, Y., La foi en 3D, Le Soleil, Cahier E, l'Université Laval, (15 septembre), p. 14, 2001.

[10] Larose, Y., Clochers et Transepts en 3D, Au fil des événements, journal de la communauté universitaire, Université Laval, (13 septembre), p. 4, 2001.

[11] Modélisation des églises de Québec en 3D : mission accomplie !, Le Carrefour de Québec, section Entente de développement culturel de Québec, (juin), 2001.

[12] Les églises de la ville de Québec, http://eglisesdequebec.org

[13] Premier site web des églises de Québec, http://eglisesdequebec.org/precedent

[14] Côté, P., Modélisation du patrimoine bâti. Les vertus du virtuel, dans Continuité, Patrimoine et technologies de l'information, Le passé dans l'œil du futur, (hiver), n 99, p. 27-29, 2003-2004.

[15] Côté, P., La conservation et la mise en valeur des lieux de culte situés sur le territoire de la Ville de Québec: Un exemple d'intervention municipale, $28^{\mathrm{e}}$ Congrès annuel de la Société pour l'étude de l'architecture au Canada (SEAC), Saint-Jean, Terre-Neuve, (11-15 juin), 2003.

[16] Côté, P., La modélisation numérique au service de la mise en valeur des églises: L'expérience de Québec (Chapitre 30), Quel avenir pour quelles églises? What future for which churches, Lucie K. Morisset, Luc Noppen, and Thomas Coomans (eds.), Collection "Patrimoine urbain", Presses de l’Université du Québec, p. 559-569, 2006. 